\title{
Contributions to the natural history of Mormopterus kalinowskii (Chiroptera: Molossidae) in the southwest of Peru
}

\author{
Marisel Flores-Quispe ${ }^{1,2 *}$, Giüseppy Calizaya-Mamani ${ }^{12}$, Gandhy Portugal-Zegarra ${ }^{1,2}$, Giovanni Aragón Alvarado ${ }^{1,2}$, Jaime Pacheco-Castillo ${ }^{3}$ \\ AND Edgardo M. RenGIFO 3,4,5 \\ 1 Programa de Conservación de Murciélagos de Perú (PCMP), Lima, Perú. E-mail: fq.marisel@gmail.com (MFQ), epiorama@gmail. \\ com (GCM), gandapz182@gmail.com (GPZ). \\ 2 Universidad Nacional Jorge Basadre Grohmann, Facultad de Ciencias, Avenida Miraflores s/n. Tacna, Perú. E-mail: gioralva@ \\ gmail.com (GAA). \\ ${ }^{3}$ Centro de Investigación Biodiversidad Sostenible (BioS), Francisco de Zela 1556, Lima 14. Lima, Perú. E-mail: biojpacheco@ \\ gmail.com (JPC), edgar mrv@outlook.com (EMR). \\ ${ }^{4}$ Universidade de São Paulo, Escola Superior de Agricultura "Luiz de Queiroz", Centro de Energia Nuclear na Agricultura, Programa \\ de Pós-Graduação Interunidades em Ecologia Aplicada. Avenida Pádua Dias, 11, São Dimas, CEP 13418-900. Piracicaba, Brasil. \\ ${ }^{5}$ Departamento de Mastozoología, Museo de Historia Natural. Universidad Nacional Mayor de San Marcos. Lima, Perú. \\ * Corresponding author
}

Mormopterus kalinowskii, is an insectivorous species restricted to the Andean western slopes of Peru and Chile, it is rare and has very scarce available information. We evaluated sex ratio, roost use, and relationship between reproductive patterns and monthly seasonal variation throughout a 13-month period. In addition, we performed the first description and characterization of its echolocation calls. The study area was located in the Ite Valley, Tacna department (southwestern Peru) at the northernmost part of the Atacama Desert, one of the driest deserts in the world. Bats were caught using mist-nets. Sex ratio in the population was calculated from all individuals captured, and its difference with regard to a 1:1 ratio was assessed through a Binomial Coefficient Test. Roost use was assessed through observation and inspection of the study area. Pearson and Spearman correlation coefficients were calculated to establish the relationship between the number of captures and temperature and precipitation data. Echolocation calls were recorded using a Petterson D240x Ultrasound detector plugged to a digital recorder. Spectrogram displays of recorded calls allowed describing structural patterns within echolocation calls and to measure frequency and time parameters. 79 individuals of $M$. kalinowskii were captured; 30 males and 49 females. Sex ratio obtained, 1:1.63, evidenced more females in the study area. M. kalinowskii uses crevices as roosts and has a single reproductive cycle per year. Higher capture rates are correlated with temperature $(r=0.526)$, but not precipitation $(r=0.096)$. Calls in search phase exhibited long duration pulses and a descending quasi-constant frequency (QCF) component from 39 to $33 \mathrm{kHz}$, reducing length and increasing bandwidth when attempting to catch prey. The sex ratio, $1: 1.63$ ( $\approx$ 2), suggests that $M$. kalinowskii is a polygamous species, as occurs in the others molossids, whereas the single annual reproductive cycle shown by $M$. kalinowskii would indicate a seasonal monoestrous reproductive pattern. Echolocation calls share several traits observed in other molossids; however, the frequency values for $M$. kalinowskii search phase pulses could be the highest recorded among the molossid bats of the Pacific coastal desert, allowing them to detect smaller prey as a strategy to mitigate food competition among insectivorous bats in arid environments.

Mormopterus kalinowskii, es una especie insectívora restringida a la vertiente occidental de Perú y Chile, monotípica y rara con muy escasa información disponible. Evaluamos la proporción de sexos, uso de refugios y la relación entre el patrón reproductivo de la especie y las épocas de calor y precipitación durante 13 meses en una población de M. kalinowskii en el Valle de Ite, departamento de Tacna (al suroeste del Perú), al comienzo del desierto de Atacama, uno de los más secos del mundo. Además, realizamos la primera descripción y caracterización de las llamadas de ecolocalización de la especie. Los murciélagos fueron capturados usando redes de niebla. La proporción de sexos en la población se calculó a partir de todos los individuos capturados, y su diferencia con respecto a una proporción 1:1 fue evaluada mediante una Prueba de Coeficientes Binomiales. El uso de refugios fue evaluado a través de la observación e inspección del área de estudio. Coeficientes de correlación de Pearson y Spearman fueron calculados para establecer la relación entre el número de capturas y datos de precipitación y temperatura. Las llamadas de ecolocalización fueron grabadas usando un detector de ultrasonido Petterson D240x conectado a una grabadora digital. Los espectrogramas de las llamadas resultantes permitieron describir patrones estructurales dentro de las llamadas y medir parámetros de frecuencia y tiempo. 79 individuos de M. kalinowskii fueron capturados; 30 machos y 49 hembras. La proporción sexual obtenida, 1:1.63, evidenció más hembras en el área de estudio. M. kalinowskii usa grietas como refugios y tiene un evento reproductivo anual. Mayores capturas están correlacionadas con la temperatura $(r=0.526)$ pero no con la precipitación $(r=0.096)$. Las llamadas en fase de búsqueda exhibieron pulsos de larga duración y un componente de frecuencia cuasi constante descendente (QCF) de 39 a $33 \mathrm{kHz}$, reduciendo su duración y aumentando su ancho de banda durante intentos de captura. La proporción de sexos, 1:1.63 $(\approx 2)$, sugiere que M. kalinowskii es una especie polígama, como ocurre en otros molósidos, mientras que un único evento reproductivo anual mostrado por M. kalinowskii indicaría un patrón reproductivo de monoestría estacional. Las llamadas de ecolocalización comparten varias características observadas en otros molósidos, sin embargo, los valores de frecuencia para los pulsos de M. kalinowskii en fase de búsqueda podrían ser los más altos de los registrados entre los molósidos del desierto costero del Pacífico, permitiéndoles detectar presas más pequeñas como una estrategia para mitigar la competencia por el alimento entre los murciélagos insectívoros en ambientes áridos.

Key words: arid; desert; echolocation; molossids; monoestry; Tacna; valley. 


\section{Introduction}

Mormopterus is a widespread bat genus of the Molossidae family, with 13 species spread throughout Africa, Oceania, Central America, and South America. Ten of these species can only be found in Africa and Oceania (M. setigeren, $M$. petrophilus, M. acetabulosus, M. francoismoutoui, M. jugularis, M. doriae, M. planiceps, M. beccarii, M. norfolkensis, and M. eleryi; Hutson et al. 2001; Jacobs and Fenton 2002; Goodman et al. 2008; McConville 2013), while the other three are only found in America (M. minutus, M. phrudus, and M. kalinowskii; Eger 2007; Mancina 2015).

The Kalinowski's Mastiff Bat, Mormopterus kalinowskii (Thomas 1983) occurs in Peru and northern Chile (Figure 1a). It is considered a rare species, due to its low frequency of capture and limited available information, and has a restricted distribution to the arid coasts, dry forests, and the highland steppes of the Andean western slopes of Peru and the arid north coast of Chile. M. kalinowskii is associated to diverse habitats from sea level to around 2,598 m elevation, mainly in inter-Andean valleys and creeks with bushy vegetation (Warner et al. 1974; Galaz and Yañez 2006; Eger 2007; Iriarte 2008; Pacheco et al. 2009; Aragón and Aguirre 2014; Pari et al. 2015). Additionally, this species occurs in low abundance in urban areas and flies quite low compared to other members of the Molossidae family (Solari et al. 2008). Eger (2007) mentions two notable records for specimens of the Yungas of Cajamarca and Cuzco departments. This author states that the record for Cuzco (AMNH 91553) had been previously identified as M. phrudus by Freeman (1981) having the district of Machu Picchu as locality for this record and that the specimen, in fact, corresponds to M. kalinowskii; however, information or support for this affirmation was not given. Under this assumption, M. kalinowskii would share habitat with M. phrudus, which has two unique records (USNM 194449; 194450) with Machu Picchu as type locality. This probable sympatry has not also been discussed by Eger (2007). Unfortunately, information of both species regarding their distribution and habitat use comes from specimens deposited in mammal collections since no study that offers natural history data exists (Eger 2007).

In the present study, we introduce natural history data that include sex ratio, roost use, and the relationship between reproduction cycles and seasonal variation in temperature and precipitation for a population of $M$. kalinowskii within the Tacna department, Peru. Additionally, we present the first description of the echolocation calls for this species as an attempt to increase the available information for bats distributed in the Pacific coastal desert, a remarkable step for the construction of acoustic libraries in the country.

\section{Materials and methods}

Study area. The research was carried out in the Ite Valley, Jorge Basadre province in Tacna department, Peru $\left(-17^{\circ}\right.$ $52^{\prime} 39.327^{\prime \prime} \mathrm{S},-70^{\circ} 58^{\prime} 23.8758^{\prime \prime} \mathrm{W}$; $82 \mathrm{~m}$; Figure $1 \mathrm{~b}$ ), which is located in the Pacific desert eco-region ( 0 to $1,000 \mathrm{~m}$; Brack
1986) towards the extreme Peruvian southwest that coincides with the border between the Coastal Peruvian desert and the Atacama Chilean desert. Here, despite the narrowness of the Ite valley and its desert surroundings, agricultural activities are conducted in the area by local residents (Figure 1c).

Fieldwork. Eight mist-nets of $12 \mathrm{~m}$ in length and $2.5 \mathrm{~m}$ wide were set up in places, such as abandoned buildings, agricultural areas, water reservoirs, and probable roosts. Mist-nets remained open overnight from 18:00 to 5:00 h of the next day and were checked at one-hour intervals (Pacheco et al. 2007; Garcés-Restrepo et al. 2016). Sampling took place over two consecutive nights per month, from January 2013 to January 2014 (13 months). The sampling effort was of 2,288 mist-net hours (88 mist-net hours per night).

Taking into consideration the similarities between Tadarida and Mormopterus genus at external level, we followed taxonomic keys made by Eger (2007) and Díaz et al. (2011). This allowed us to identify M. kalinowskii individuals based on measurements of the forearm ( 34.4 to $39 \mathrm{~mm}$ ) and the external morphological characters, such as pale gray hair, wrinkled lips with deep folds, separated ears with a reduced keel, a well-developed tragus, a wider than high antitragus, and one upper premolar. To avoid bias by recapture, a piece of hair was cut on the right side of the dorsum.

The bats were examined to determine their age, sex, and reproductive stage. The age of each bat was obtained through the observation of the ossification degree of the large bones of the wings allowing us to differentiate among adults, sub adults, and juveniles (Paz and Benzal 1990). The reproductive stage was determined by the observation and palpation of their genitals; males were categorized in accordance to the position of their testicles: non-reproductive males (abdominal position) and reproductive males (scrotal position). While this is not definitive to determine the reproductive condition of male bats (Racey 2009), it is wellknown that in most bats spermatogenesis process requires low temperatures, triggering that testes to be found external to the body, inside an external sac, and in inguinal or scrotal position (Garrido-Rodriguez et al. 1984; Krutzsch 2000). Males of certain species of bats have permanent abdominal testes, coinciding the spermatogenesis with hibernation that favors spermatozoids generation (Bernard and Tsita 1995). Some species can even have migratory testes, moving them from the abdomen to the scrotum or to the inguinal ring daily or seasonally for reproduction (Baker and Baker 1936; Ratcliffe 1932; Krutzsch and Crichton 1987). Since in the tropical and subtropical regions of the Old and the New World the reproductive pattern of male bats is timed to that of females and is given in response to optimal ecological and nutritional conditions (Krutzsch 2000), in this study, we consider the scrotal position as a sign that evidences the reproductive activity of males of $M$. kalinowskii. In the case of the reproductive stage of females, they were classified as non-reproductive (with closed vagina, normal abdomen, reduced breast, or without pigmentation) and 
reproductive (with open vagina, and in stage of pregnancy or lactation) (Kunz et al. 1996; León 2004; Racey 2009).

In order to determine the sex ratio of the species, we divided the total number of females by the total number of males obtained during the sampling, the result was used to establish a population sex ratio. Then, a Binomial Coefficient Test was performed to assess if the sexual proportion obtained was significantly different from a 1:1 relation (Pérez-Lustre and Santos-Moreno 2010; Santos-Moreno et al. 2010). This criterion may be used to infer the existence of monogamy or polygamy among the population (SantosMoreno et al. 2010). Following Graham (1988), we explored about seven kilometers around the study area in order to look for some probable roosts of $M$. kalinowskii, taking into account roosting features of the Molossidae family, presence of guano (feces) and asking local people for information regarding the presence of bats.

Data analysis. We obtained temperature and precipitation data from the SENAMHI (Servicio Nacional de Meteorología e Hidrología del Perú). These data were correlated with the number of captures of $M$. kalinowskii. Previously to the statistical analysis, both number of captures and climatic variables were subjected to a Shapiro-Wilk normality test in order to know whether applying Pearson or Spearman correlations. The statistical analysis was performed through the software STATGRAPHIC Centurion XVI, version 16.1.11 (StartPoint Technologies Inc. 2010).
Ultrasound recording. We used the Pettersson D240x ultrasound detector (Pettersson Elektronik $A B$, Uppsala, Sweden) in heterodyne mode for real-time pulse detection and the time-expansion mode to convert $3.4 \mathrm{sec}-$ onds-length segments into recorded audible sequences ten times longer. The detector was plugged to a Tascam DR-100 digital recorder (Teac America Inc., California, USA), with the following settings: sampling rate of $44.1 \mathrm{kHz}$ and 16-bit virtual resolution for stereo PCM wav recordings.

Ultrasonic vocalizations recorded several seconds after hand-released bats took flight allowed us to obtain echolocation calls mostly in search phase. Therefore, reference calls were used to identify the acoustic repertoire of free flying M. kalinowskii individuals in the area (Rodríguez-San Pedro et al. 2015).

Analysis of recordings. Spectrograms obtained from field recordings were analyzed using the software Avisoft SASLab Pro 5.2 (Avisoft Bioacoustics, Germany). Spectrogram parameters were set at a sampling rate of $44.1 \mathrm{kHz}$, a 256 point FFT (Fast Fourier Transform) and 75 \% Hamming window overlap. Other settings were part of the default software configuration. We chose pulses with a signal to noise ratio over $20 \mathrm{~dB}$ (Russo and Jones 2002) and measured six quantitative acoustic parameters: a) initial frequency, b) final frequency, c) maximum amplitude frequency (peak frequency), d) bandwidth (difference between the maximum and minimum frequency values), e) pulse duration,

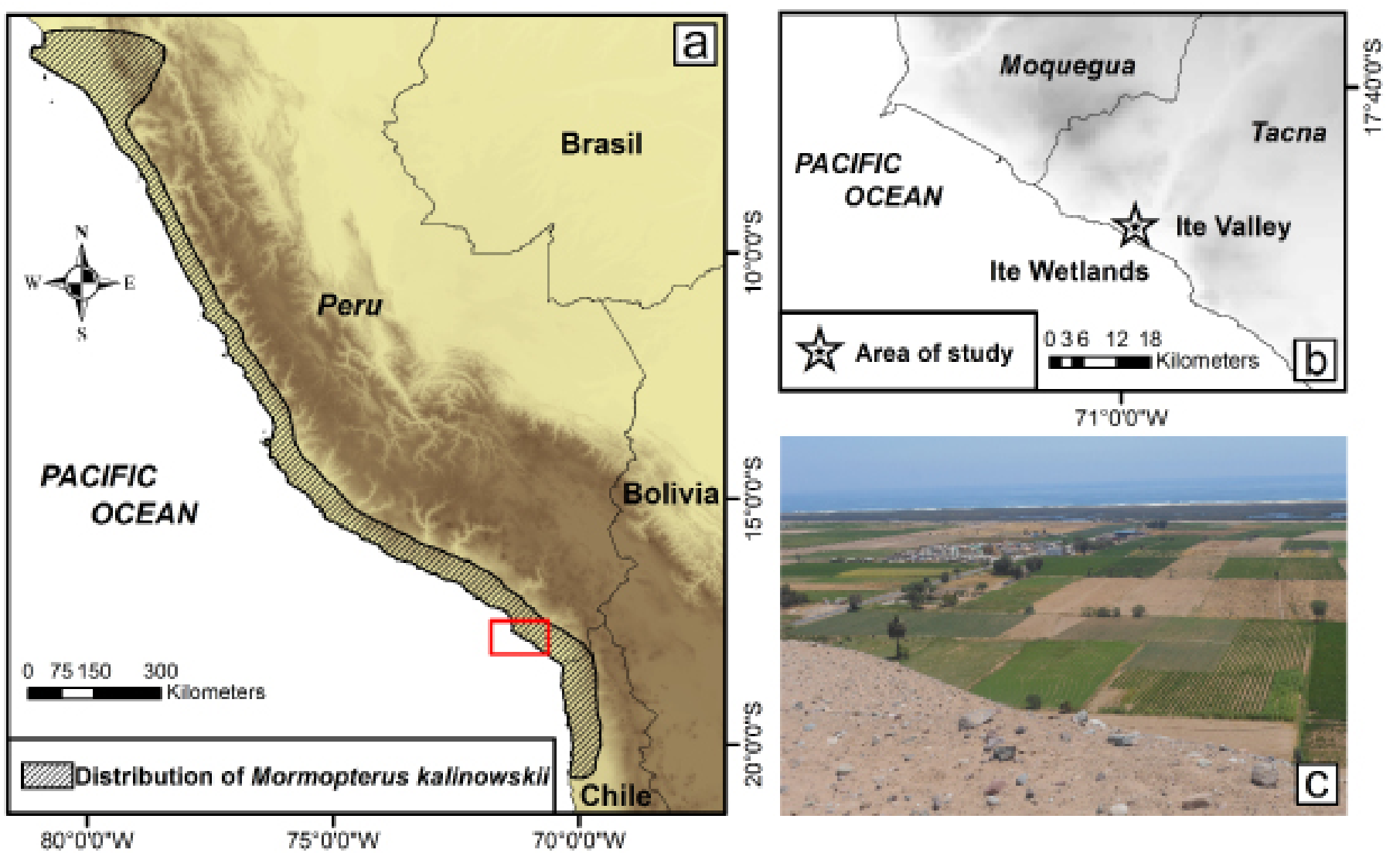

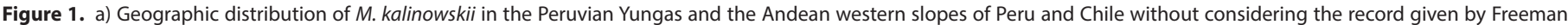

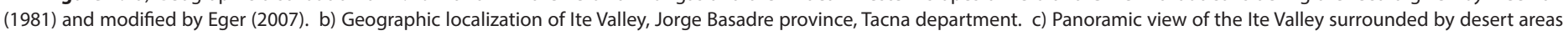
and agricultural lands. 
and f) interpulse duration (Papadatou et al. 2008). To prove if acoustic parameters within the calls from released and free-flying bats belong to the same species, a Wilk's Lambda value was assessed for statistical significance with a multivariate analysis of variance (MANOVA).

In addition, we described structural qualitative traits such as harmonics presence and frequency components sequence (pulse shape in spectrogram according to a modulated or constant frequency). Descriptive statistics (mean \pm standard deviation) were calculated for each echolocation phase registered in the acoustic recordings (search, approach, and terminal phase).

\section{Results}

A total of 79 individuals of M. kalinowskii (Figure 2) were captured: 49 females ( 43 adults, 2 sub-adults, 4 juvenile) and 30 males ( 23 adults, 5 sub-adults, 2 juvenile). Of these, 31 females and 17 males were in reproductive stage (3 pregnant females, 28 lactating females, and 17 males with descended testes).

The sex ratio estimated was of 1:1.63. The binomial coefficient test showed that this sexual proportion differed statistically $(Z=2.025 ; g . \mathrm{I} .=1 ; P=0.043)$ from $1: 1$, suggesting more than one female per male, so we might infer that there would be almost a relation 1:2 $(1.63 \approx 2)$; two females per each male, which is discussed later.

After walking the arid hills that surround the Ite Valley, potential roost sites of $M$. kalinowskii were identified, based

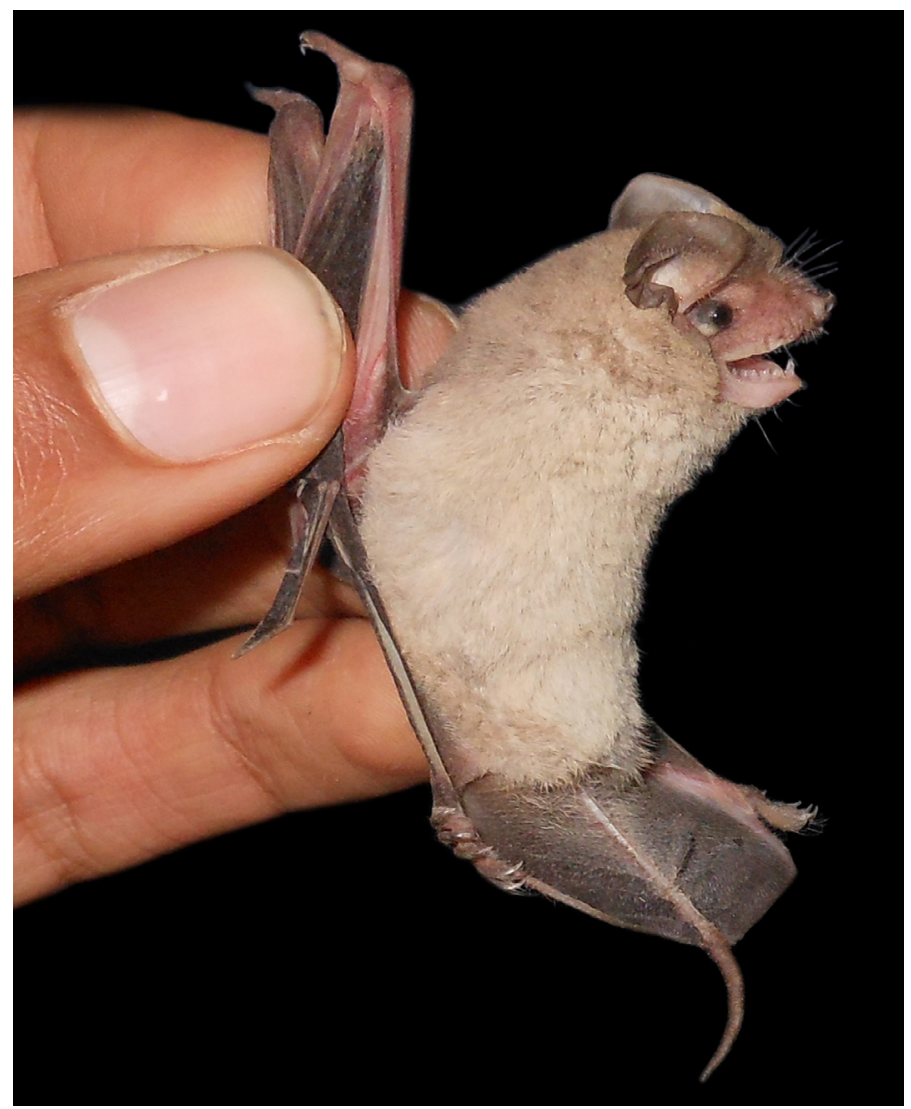

Figure 2. Adult male specimen of $M$. kalinowskii after being captured using mist nets in the Ite Valley, Jorge Basadre province, Tacna department, Peru. on the presence of narrow crevices situated about $3 \mathrm{~m}$ above gravel slopes of at least $50 \mathrm{~m}$ (remnant sediments of an ancient river). The presence of feces inside the crevices confirmed they had been recently occupied by bats. On one occasion during the survey, 203 individuals were counted leaving a gravel crevice, those are very likely to have been $M$. kalinowskii individuals due to their color and size, and because when we made a closer inspection of the roost, this still had individuals of the species inside about to fly. Thus, we believe this would be a colony of this species.

January $(2013,2014)$ and February (2013), during the dry season, and December (2013), at the end of the wet season, were the months with the highest number of captures. The extensive dry season was characterized by the lack of precipitation with temperatures between $28.8^{\circ} \mathrm{C}$ (February) and $10.2^{\circ} \mathrm{C}$ (June). The captures increased towards December during the wet season with temperatures between 10 ${ }^{\circ} \mathrm{C}$ (July) and $26{ }^{\circ} \mathrm{C}$ (December). These temperatures were accompanied by small peaks of light precipitation (typical in arid environments) during August $(0.3 \mathrm{~mm})$, September $(1.1 \mathrm{~mm})$ and December $(0.4 \mathrm{~mm})$. After applying ShapiroWilk test, precipitation data did not exhibit a normal distribution ( $p<0.05$ ); hence, Pearson correlation was used to analyze data of bat captures and temperature, while Spearman correlation for assessing data of bat captures and precipitation. Pearson correlation coefficient confirmed a moderate correlation between the number of captures and temperature $\left(r=0.526, r^{2}=0.277, p=0.065\right)$. In contrast, the Spearman coefficient showed no correlation between the number of captures and precipitation (Spearman correlation coefficient $=0.096, p=0.754$ ).

On the other hand, reproductive individuals were reported mainly during the dry season (January-February) with females being pregnant or in the period of lactation (January-February-December). Reproductive activity peaks of the species, evidenced by a higher number of captures of individuals in reproductive stage, occurred in January ( 1 male and 12 females), February ( 2 males and 2 females), and December ( 3 males and 11 females) in 2013, and January (4 males and 6 females) in 2014. Those were, coincidentally, the months with higher temperatures and very light or null precipitation. We also captured 6 reproductive males from June to September in 2013. However, reproductive females were only captured in the months of reproductive activity peaks, being absent during the rest of the study (Figure 3). Along the assessment, 48 (60.76\%) individuals showed reproductive activity, $3(6.25 \%)$ females were pregnant and $28(58.33 \%)$ lactating. With regard to reproductive males, $17(35.42 \%)$ showed descended testes. On the contrary, $31(39.24 \%)$ individuals were non-reproductive, 18 (58.06 $\%)$ females and 13 (41.94 \%) males.

Acoustic evaluation. M. kalinowskii recordings sequences were obtained from five captured and 23 free-flying individuals. No statistically significant differences were found in acoustic parameters between released and free-flying bats (MANOVA, Wilk's Lambda $=0.685, \mathrm{~F}_{(6,21)}=1.613, p>0.05$ ). 


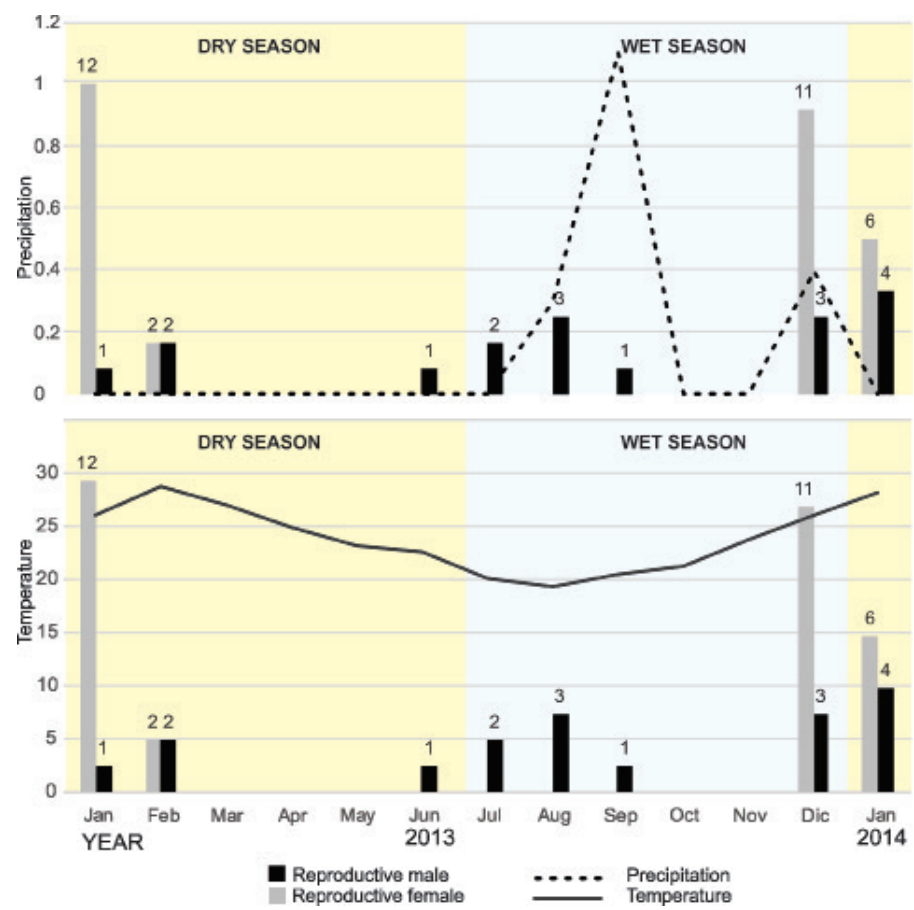

Figure 3. Reproductive females (in black) and reproductive males (in gray) with respect to the environmental temperature and precipitation.

Echolocation calls showed sequences of pulses divided into search, approach, and terminal phases, although few sequences with all three echolocation phases were recorded (Figure 4). In sequences of up to 3.4 seconds, 70 $\%$ of the time corresponded to the search phase, $21 \%$ to the approach phase and $9 \%$ to the terminal phase.

Search phase calls consisted of pulses with one harmonic and a flat or slightly concave shape displayed on the spectrogram. These pulses had short bandwidths $(<$ $4 \mathrm{kHz}$ ) because of a mild decrease in ultrasonic frequency over time, which was represented by a downward quasiconstant frequency component (dQCF). The search pulse frequency parameters ranged from $39 \mathrm{kHz}$ to $33 \mathrm{kHz}$ and exhibited a longer duration and pulse interval than the subsequent phases (Table 1; Figure 4a).

The approach phase consisted of one-harmonic pulse with pronounced concave shape. Moreover, pulses showed a broad bandwidth which was on average four times greater than the search phase, and an abrupt decline in frequency in the first half of the pulse followed by a slight decrease in the last half, representing a sequence of

Table 1. Descriptive statistics (mean \pm standard deviation) for acoustic parameters in pulses from three echolocation phases of M. kalinowskii. IF: Initial Frequency. FF: Final Frequency. PF: Peak Frequency. BW: Pulse Bandwidth. D: Duration. PI: Pulse Interval.

\begin{tabular}{cccc}
$\begin{array}{c}\text { Acoustic } \\
\text { Parameter }\end{array}$ & $\begin{array}{c}\text { Search phase } \\
(n=\mathbf{3 7} \text { pulses; 26 } \\
\text { calls) }\end{array}$ & $\begin{array}{c}\text { Approach phase } \\
(n=\mathbf{1 1} \text { pulses; } \mathbf{3} \\
\text { calls })\end{array}$ & $\begin{array}{c}\text { Terminal phase } \\
(n=\mathbf{2 1} \text { pulses; 2 } \\
\text { calls) }\end{array}$ \\
\hline IF (kHz) & $36.8 \pm 2.6$ & $51.5 \pm 6.4$ & $39.4 \pm 4.9$ \\
FF (kHz) & $33.6 \pm 0.8$ & $37.6 \pm 1.9$ & $24.1 \pm 1.9$ \\
PF (kHz) & $34.6 \pm 1.1$ & $40.3 \pm 2.0$ & $30.8 \pm 1.4$ \\
BW (kHz) & $3.2 \pm 2.3$ & $13.9 \pm 6.8$ & $15.3 \pm 3.4$ \\
D (ms) & $10.7 \pm 1.4$ & $7.6 \pm 2.5$ & $1.8 \pm 0.3$ \\
PI (ms) & $211.3 \pm 76.9$ & $75.2 \pm 16.1$ & $9.1 \pm 6.3$ \\
\hline
\end{tabular}

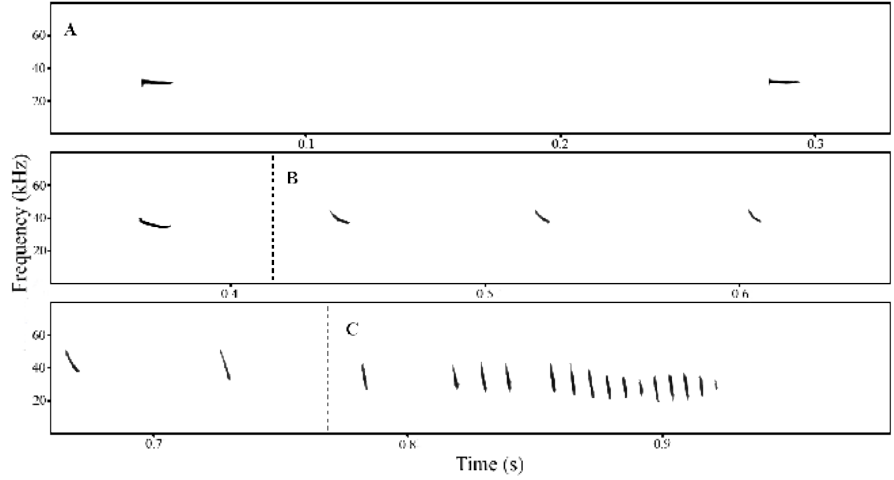

Figure 4. Echolocation call of a free-flying individual of $M$. kalinowskii displayed in a time-frequency spectrogram. a) Search phase. b) Approach phase. c) Terminal phase. View from Avisoft SAS-Lab Pro 5.2, software for bat call analysis. Sampling rate adjusted to $160 \mathrm{kHz}$.

a downward modulated frequency component (dFM) followed by a dQCF component. During the approach phase, bats emitted pulses ranging between $50 \mathrm{kHz}$ to $37 \mathrm{kHz}$ with shorter duration and pulse intervals than in search phase (Table 1; Figure 4b).

Terminal phase calls consisted of sequences of very short rapid pulses. The average bandwidths for terminal phase pulses were the highest compared to other phases and comprised a frequency range between $45 \mathrm{kHz}$ and $25 \mathrm{kHz}$. The sharp decline in frequency values over time resulted in a structure defined by a dFM component (Table 1; Figure 4c).

\section{Discussion}

Knowledge about natural history of species in the genus Mormopterus in South America is poor (Eger 2007). There are no precedents of previous research related to species of this genus, thus, many aspects of $M$. kalinowskii remain unknown. This survey represents a novel source of information about the genus and the target species.

Sex proportions of different mammals have been evaluated in the Neotropics (Santos-Moreno et al. 2007; PérezLustre and Santos-Moreno 2010; Pérez-Irineo and SantosMoreno 2014), however, this aspect is still unknown for most of species. The measure of sex proportions in bats as an indirect indication to determine the likelihood of monogamy or polygamy was made for some Mexican bat species like Dermanura tolteca and Centurio senex, applying a test based on binomial coefficients to assess the statistical significance of a sexual ratio different from 1:1 (GarcíaGarcía et al. 2010; Santos-Moreno et al. 2010). Precisely, the sexual proportion that we obtained for M. kalinowskii (1:1.63) was statistically different from a 1:1 ratio when applying this test, suggesting that it is a polygamous species (with polygynous males). This is a common sexual trait, both in molossid species of the New World (Molossus pretiosus and Tadarida brasiliensis) and in species from the Old World (Mops condylurus and Mormopterus planiceps; McCracken and Gustin 1991; Bouchard 2001; Krutzsch et al. 2002; Keeley and Keeley 2004; Krutzsch and Crichton 2005; Nogueira et al. 2008; Ortega and Martínez-Rodríguez 2011). 
In this sense, M. kalinowskii is likely a promiscuous species, which makes it possible to infer social structure and association conforming mixed groups based on the relation of almost two females for each male (Ortega et al. 2010; Keeley and Keeley 2004). Nonetheless, we cannot infer a mating system for the species because the possible existence of "harems" or other mating groups needs to be thoroughly proven (McCracken and Wilkinson 2000).

With regards to reproductive pattern, it is important to point out that a reproductive cycle is usually understood as the period where several reproductive events (mating, pregnancy, births, lactation, and parental care) take place (Martin and Bernard 2000). Our fieldwork data showed that the target species has a single annual reproductive cycle shown by females in reproductive stage and it would last from the end of June to February. Therefore, M. kalinowskii is likely to follow a seasonally monoestrous reproductive pattern. Fabian and Marques (1989) and Ortega and Martínez-Rodríguez (2011) concluded that in molossids species of the New World, this kind of reproductive pattern is linked to environmental conditions, which suggests that in M. kalinowskii this event would occur in a time where individuals have the best chances for their successful reproduction. Polyestry, and going into estrus soon after giving birth on the other hand, are less common in the family since these traits have only been reported for species in the genera Molossus and Eumops. Initially, species, such as Molossus molossus and $M$. ater were considered as monoestrous (Krutzsch and Crichton 1985; Fabian and Marques 1989), however, it was later reported that $M$. molossus has up to three reproductive cycles with different durations (Fabian and Marques 1989; Alberico et al. 2005). At this point, monoestrous cycles in M. kalinowskii cannot directly be linked to local food availability because there is not a quantitative analysis of the temporal variability of the alimentary resources (insects) in the Ite Valley. Nevertheless, the relationship between the abundance of food and the reproductive cycles of bats is well-recognized (Fleming et al. 1972; Wilson 1979; Mena and Williams 2002; Aguirre 2007). This evidence appears to suggest a strong delimitation in reproductive periods of insectivorous bats based on the availability of insects (Fleming et al. 1972) because of the great energetic demand that these events involve (Racey 1982; Zortéa 2003).

The mating season of $M$. kalinowskii was shown to occur between the end of fall and the onset of winter, that is, at the end of June and the beginning of July (transition to the wet season) unlike other species of insectivores (molossids and vespertilionids) of the eastern Andean slopes of Peru (dry season; Graham 1989; Ascorra et al. 1996). Consequently, our results suggest that pregnancy of $M$. kalinowskii would occur between the end of winter and the onset of spring, that is to say, late September and early October (wet season) with births at the beginning of the summer (around late December and in transition to the dry season) unlike other monoestrous species of molossids with births associated only to spring in the New World (wet season; Fabian and
Marques 1989). For Peruvian bats, Graham (1989) reported $22.2 \%$ of births during both seasons for some insectivorous species, as would occur for M. kalinowskii. Additionally, Graham (1989) mentioned that bat species from the Pacific coastal and slope region of Peru showed a high rate of births in the dry season, reinforcing and supporting our results for M. kalinowskii. Along the field survey, lactation in our target species was only registered during summer in December, January and February (transition to dry season onwards). This has a strong relation to the pattern recently described by Pari et al. (2015), who reported four lactating females for Arequipa department (north of Tacna), two in November and two in March, months adjacent to the limits of our findings for lactation of the species. Based on what has been described, this further supports our data and suggests a relationship between the environmental temperature and the reproduction in accordance with Pearson correlation, where the number of captures of $M$. kalinowskii shows a significant correlation with temperature, which varied between $28.8^{\circ} \mathrm{C}$ and $10^{\circ} \mathrm{C}$ during 13 months of survey (SENAMHI 2017).

It is necessary to mention that the value of Pearson correlation coefficient does not imply causation but an important degree of association between variables (Cangelosi et al. 1983; Rebekić et al. 2015). While it is true that the resultant $p$-value (0.06) for Pearson correlation coefficient seems to be statistically non-significant, it is very close to the typical $p$-value of 0.05 used to express statistical significance and would indicate a $93.5 \%$ of probability of our variables being truly related and not merely by chance (Fenton and Neil 2013). In fact, we also used the coefficient of determination $\left(r^{2}\right)$, which has been used in several researches as a stable measure of the relation between two variables (Taylor 1990; Rebekić et al. 2015) since $p$-value is highly influenced by the sample size and number of pairs of data (Ziliak and McCloskey 2008). In this case, the value of the coefficient of determination obtained $\left(r^{2}=0.277\right)$ explains the $27.7 \%$ of the direct and positive relationship between the number of captures and temperature (Kehr 1994).

Thus, M. kalinowskii are likely to be mating during the colder months and taking advantage of the warmer months of the year, with more favorable environmental conditions, for pregnancy, births, and lactation (Mena and Williams 2002). Similarly, the reproductive cycle of insectivorous species, such as Promops davisoni, Myotis atacamensis, Histiotus macrotus, Histiotus montanus, and Tadarida brasiliensis, with which M. kalinowskii shares habitat (Aragón and Aguirre 2014; Flores et al. 2015), is also likely to be influenced by temperature. In regard to precipitation, Spearman correlation showed no relationship between the number of captures of $M$. kalinowskii and rain events, possibly as a consequence of low and inconsistent rain in the Ite Valley. Individual rain events in this area reached a maximum of $4 \mathrm{~mm}$ at the time of assessment, however, a real relationship between the number of captures and precipitation must not be discarded because so small values of the latter could make it difficult to measure. Consequently, the per- 
centage in response to a single environmental factor about the relationship between the number of captures and temperature, as well as the numerical results obtained from the relationship between the number of captures and precipitation could be increased and made measurable, respectively when more detailed researches involving other environmental factors potentially related to the reproductive pattern of $M$. kalinowskii are completed and give us a better approach of how reproduction of the species behaves in relation with the environment.

All crevices used as roosts by $M$. kalinowskii were found at least 53 meters above the ground; this is consistent with the characteristics described for roosts of molossids species. Since they, in general, have narrow wings, roosts of many species of the Molossidae family must be located in high places, such as buildings, escarpments, and trees in order to reach enough speed to take the necessary impulse to fly over the ground (Vaughan et al. 2015). Galaz and Yañez (2006), Iriarte (2008), and Aragón and Aguirre (2014) also report $M$. kalinowskii living in crevices along hills, consistent with other members of the Molossidae family which have been studied in the Pacific coastal desert in southern Peru, such as Molossus molossus, Nyctinomops aurispinosus, N. laticaudatus, N. macrotis, P. davisoni, T. brasiliensis, and Tomopeas ravus. These species, besides of living in hillside crevices, are also reported to be found in human constructions, caves, abandoned mines, cliffs, and hollow trees (Pari et al. 2015).

We counted approximately 203 individuals leaving their roosts, being the highest quantity of individuals of the target species reported up to now, but an inferior number in comparison to other colonies of molossids like Molossus molossus in Colombia, where more than 500 individuals have been registered roosting in human buildings, or Tadarida brasiliensis in Mexico and Argentina with records ranging from 700,000 to millions of individuals, respectively (Barquez and Díaz 2001; Alberico et al. 2005; Gándara et al. 2006). The differences with M. kalinowskii represent different social structures and ecology given by important factors, like the environment where these species live, food and roost resource availability, and their own evolutionary history (Kunz 1982; Olival 2012).

The acoustic recording analysis was achieved to describe the echolocation calls of Kalinowski's mastiff bat. Pulses in search, approach, and terminal phases suggest that $M$. kalinowskii is adapted to detect and locate small insects in open spaces as observed around their natural roosts in the Ite valley. We recognized three acoustical traits shared between single search phase pulses emitted by M. kalinowskii and other species of the Molossidae family: a) longduration pulses over $10 \mathrm{~ms}, \mathrm{~b}$ ) pulse structure defined by a quasi-constant frequency component, and c) a narrow bandwidth (Jung et al. 2014). Moreover, these traits may allow a rapid and efficient discrimination among M. kalinowskii and other bats that cohabit in the southern region of the Pacific desert like vespertilionids, such as $H$. montanus, H. macrotus, and M. atacamensis (Aragón and Aguirre 2014), which produce short-duration search pulses (less than 7 $\mathrm{ms}$ ) with broad bandwidth and pulse structure corresponding to a modulated frequency followed by a quasiconstant frequency component (Ossa et al. 2015; Pacheco et al. 2015; Rodríguez-San Pedro et al. 2015).

Another species of the genus Mormopterus (M. minutus) exhibits plasticity in the design of search phase pulses as an adaptation for efficient prey detection in areas of variable vegetation cover with pastures and forests patches of different height (Mora et al. 2011). However, no evidence of plasticity was found in M. kalinowskii as all echolocation calls were recorded in a habitat constituted by extensive arid zones and low-altitude shrub vegetation. The approach and terminal phase pulses of $M$. kalinowskii are very similar to those described for M. minutus and molossids in general (Mora et al. 2011), where bandwidth increases up to three times more than in search phase. Duration and pulse interval are gradually reduced, which allows a better determination of the distance, position, size, and shape of the prey (Simmons and Stein 1980).

From our research, $M$. kalinowskii can be considered as one of the species of the Molossidae family with the highest frequency parameters for pulses in search phase, since it is known that the majority of molossids emit pulses between $15 \mathrm{kHz}$ and $40 \mathrm{kHz}$ (Jung et al. 2014). In addition, based on the inverse ratio between maximum amplitude frequency and detectable prey size (Jones 1999), this species is able to detect the smallest prey compared to other molossids in the Pacific coastal desert (Aragón and Aguirre 2014; Rodriguez-San Pedro et al. 2016), which may provide some clues about possible mitigation of food competition, thus warranting future research on this topic.

The results of this study showed that $M$. kalinowskii in the Ite Valley, Tacna department, has a polygamous mating system (promiscuous), the reproductive pattern is seasonal monoestrus with mating during the colder months (July and August) of the wet season and births during the warmer months (November, December, and January), where the species finds favorable conditions for raising young. It was observed that this species uses hillside crevices as roosts where there could be hundreds of individuals living together.

The acoustic analyses described the echolocation calls of M. kalinowskii for the first time, detecting and identifying M. kalinowskii employing bioacoustics methods. The Kalinowski's mastiff bat's echolocation calls consist of long and quasiconstant frequency pulses during the search for insects which are shortened and vary their frequency sharply as they approach prey in the air when attempting to capture it. The design of M. kalinowskii search phase pulses meets the expected characteristics for the Molossidae family; however, the frequency at which they are emitted could be considered one of the highest reached among the free-tailed bats known to inhabit the Chilean-Peruvian Pacific coastal desert. This allows $M$. kalinowskii to detect 
smaller prey, leading to a possible mitigation of resource competition between insectivorous bats in desert areas.

\section{Acknowledgements}

Our deepest acknowledgements to M. Oversluijs Alvarado, Y. Ticona Laqui, K. Neyra Chata, S. Marmanillo Calderón, J. Ticona Rafael, J. C. Suaña Paco, and M. Flores Arratia for their invaluable assistance during the performance of the field tasks; and Julian Flores Choque for the financial support in great part of this work. We also want to give thanks to all the members of the Programa de Conservación de Murciélagos de Perú (PCMP), Sede Tacna, T. Lanchipa Ale and A. Cáceres Huambo for their recommendations and advice, and all of whom gave their collaboration and hospitality during the fieldwork carried out in the Ite Valley. To V. Pacheco Torres, C. Jiménez Aguado, E. Arias Arone, S. Velazco Salvatierra, and M. Peralta Utani, of the Departamento de Mastozoología of the Museo de Historia Natural of the Universidad Nacional Mayor de San Marcos for their advice. Finally, we are thankful to J. Charters who helped improve the language of this manuscript and R. S. Voss (American Museum of Natural History) for his suggestions in using some terms in English language during the final review of this work.

\section{Literature cited}

AguiRRE, L. 2007. Historia natural, Distribución y Conservación de los Murciélagos de Bolivia. Centro de Ecología y Difusión Simón Patiño. Santa Cruz de la Sierra, Bolivia.

Alberico, M., C. A. SaAvedra, and H. García-Paredes. 2005. Murciélagos caseros de Cali (Valle del Cauca-Colombia). Caldasia 27:117-126.

Aragón, G., AND M. AguirRe. 2014. Distribución de murciélagos (Chiroptera) en la región de Tacna, Perú. Idesia 32:119-127.

Ascorra, C. F., S. Solari, and D. E. WiLson. 1996. Diversidad y ecología de los quirópteros en Pakitza. Pp. 585-604 in Manu, the Biodiversity of southeastern Peru (Wilson, D. E. and A. Sandoval, eds.). Editorial Horizonte. Lima, Perú.

BAKER, J. R., AND Z. BAKER. 1936. The seasons in a tropical rainforest (New Hebrides). Part 3. Fruit-bats (Pteropodidae). Journal of the Linnean Society (Zoology) 40:123-141.

Barquez, R. M., AND M. M. Díaz. 2001. Bats of the Argentine Yungas: a systematic and distributional analysis. Acta Zoológica Mexicana 82:1-81.

BernaRd, R. T. F., AND J. N. TSITA. 1995. Seasonally monoestrous reproduction in the molossid bat, Tadarida aegyptica, from low temperate latitudes $\left(33^{\circ} \mathrm{S}\right)$ in South Africa. South African Journal of Zoology 30:18-22.

BOUCHARD, S. 2001. Sex discrimination and roostmate recognition by olfactory cues in the African bats, Mops condylurus and Chaerephon pumilus (Chiroptera: Molossidae). Journal of Zoology 254:109-117.

Brack, A. 1986. Las ecorregiones del Perú. Boletín de Lima 44:57-70.

Cangelosi, V. E., P. H. Taylor, and P. F. Rice. 1983. Basic statistics: A real world approach, third edition. West Publishing Co. Minnesota, USA.

Díaz, M. M., L. F. Aguirre, and R. M. Bárquez. 2011. Clave de identificación de los murciélagos del cono sur de Sudamérica. Imprenta ETREUS. Cochabamba, Bolivia.

Eger, J. L. 2007. Family Molossidae P. Gervais, 1986. Pp. 399436 in Mammals of South America, Volume 1. Marsupials, xenarthrans, shrews, and bats (Gardner, A. L. Ed.). The University of Chicago Press. Chicago, USA.

FABIAN, M. E., AND R. V. MARQues. 1989. Contribuição ao conhecimiento da biologia reprodutiva de Molossus molossus Pallas, 1766 (Chiroptera: Molossidae) en Brazil. Revista Brasileira de Zoologia 6:603-610.

Fenton, N., AND M. Nell. 2013. Risk assessment and decision analysis with bayesian networks. CRC Press. New York, USA.

Fleming, T. H., E. T. Hooper, AND D. E. WILSON. 1972. Three Central American bat communities: structure, reproductive cycles and movement patterns. Ecology 53:653-670.

Flores, M., G. Calzaya, V. Pacheco, and G. Aragón. 2015. Distribution of Promops davisoni Thomas, 1921 (Chiroptera: Molossidae) in Peru with a new record and southward range extension. Check List 11:1573.

FreEMAN, P. W. 1981. A multivariate study of the family Molossidae (Mammalia, Chiroptera): Morphology, ecology, evolution. Fieldiana, Zoology 7:1-13.

Galaz, J., AND J. Yánezz. 2006. Los Murciélagos de Chile. Guía para su reconocimiento. Ediciones del Centro de Ecología Aplicada. Santiago, Chile.

Gándara, G., A. N. Correa, and C. A. Hernández. 2006. Valoración económica de los servicios ecosistémicos que prestan los murciélagos Tadarida brasiliensis como controladores de plagas en el norte de México. Working Papers, Escuela de Graduados en Administración Pública y Políticas Públicas, Campus Monterrey 2006:1-18.

Garcés-Restrepo, M. F., A. Giraldo, C. López, and N. F. Ospina-Reina. 2016. Diversidad de murciélagos del Campus Meléndez de la Universidad del Valle, Santiago de Cali, Colombia. Boletín Científico. Centro de Museos. Museo de Historia Natural 20:116-125.

García-Garcia, J. L, A. Santos-Moreno, and A. Rodríguez-Alamilla. 2010. Population dynamics of the bat Dermanura tolteca (Chiroptera: Phyllostomidae) in a tropical forest in Mexico. Revista de Biología Tropical 58:1323-1334.

Garrido-Rodriguez, D., P. Fuentes-Servin, M. Gasca-Boyer, and S. JuÁrez-VergaRA. 1984. Patrón de reproducción del murciélago insectívoro Pteronotus parnellii mexicanus Miller, 1902 (Chiroptera: Mormoopidae). Revista de Biología Tropical 32:253-262.

Goodman, S., J. Vuuren, F. Ratrimomanarivo, J. Probst, and R. Bowie. 2008. Specific status of populations in the Mascarene Islands referred to Mormopterus acetabulosus (Chiroptera: Molossidae), with description of a new species. Journal of Mammalogy 89:1316-1327.

Graham, G. L. 1988. Interspecific associations among Peruvian bats at diurnal roosts and roost sites. Journal of Mammalogy 69:711-720.

Graham, G. L. 1989. Seasonality of Reproduction in Peruvian Bats. Fieldiana, Zoology 39: 173-186.

Hutson, A. M., S. P. Mickleburgh, and P. A. Racey. 2001. Microchiropteran bats: global status survey and conservation action plan. IUCN/SSC Chiroptera Specialist Group, IUCN. Information Press. Oxford, UK. 
Iriarte, A. 2008. Mamíferos de Chile. Lynx Editions. Barcelona, España.

JACOBS, D., AND M. FENTON. 2002. Mormopterus petrophilus. Mammalian Species 703:1-3.

JONES, G. 1999. Scaling of echolocation parameters in bats. Journal of Experimental Biology 202:3359-3367.

Jung, K., J. Molinari, And E. K. Kalko. 2014. Driving factors for the evolution of species-specific echolocation call design in new world free-tailed bats (Molossidae). PLoS ONE 9:e85279.

Keeley, A. T. H., and B. W. Keeley. 2004. The mating system of Tadarida brasiliensis (Chiroptera: Molossidae) in a large highway bridge colony. Journal of Mammalogy 85:113-119.

KeHR, A. 1994. Usos y abusos de las correlaciones en biología. Cuadernos de Herpetología 8:225-228.

KRUTZSCH, P. H.2000. Anatomy, Physiology and Cyclicity of the Male Reproductive Tract. Pp. 92-137 in Reproductive Biology of Bats (Crichton, E. G., and P. H. Krutzsch, eds.). Academic Press. London, UK.

Krutzsch, P. H., ANd E. G. CRIChton. 1985. Observations on the reproductive cycle of female Molossus fortis (Chiroptera: Molossidae) in Puerto Rico. Journal of Zoology 207:137-150.

Krutzsch, P. H., and E. G. CRIChton. 1987. The reproductive biology of the male little mastiff bat, Mormopterus planiceps (Chiroptera: Molossidae) in southeastern Australia. The American Journal of Anatomy 178:369-386.

KrUtzsch, P. H., T. H. Fleming, AND E. G. CRICHTON. 2002. Reproductive biology of male Mexican free-tailed bats (Tadarida brasiliensis mexicana). Journal of Mammalogy 83:489-500.

KRUTZSCH, P. H., AND E. G. CRICHTON. 2005. Reproductive biology of the male little mastiff bat, Mormopterus planiceps (Chiroptera: Molossidae), in Southeast Australia. American Journal of Anatomy 178:352-368.

Kunz, T. H. 1982. Roosting Ecology. Pp. 1-46 in Ecology of bats (Kunz, T. H. Ed.). Plenum Press. New York, USA.

Kunz, T. H., C. Wemmer, and V. Hayssen. 1996. Sex, age, and reproductive condition of mammals. Pp. 279-290 in Measuring and monitoring biological diversity, standard methods for mammals (Wilson, R., C. Nichols, and R. Foster, eds.). Smithsonian Institution Press. Washington, U. S. A.

LEÓN, P. N. 2004. Estudio preliminar de los patrones reproductivos de Dermanura phaeotis y Artibeus intermedius (Chiroptera: Phyllostomidae) en petenes del noreste de la península de Yucatan, México. Tesis de Pregrado, UADY, Mérida, Yucatán, México.

Mancina, C. 2015. Mormopterus minutus. In: IUCN. 2017. The IUCN Red List of Threatened Species. Version 2017.3. www. iucnredlist.org. Consulted on February $27^{\text {th }} 2018$.

Martin, L., ANd R. T. F. Bernard. 2000. Endocrine regulation of reproduction in bats: The role of circulating gonadal hormones. Pp. 27-64 in Reproductive Biology of Bats (Crichton, E. G., and P. H. Krutzsch, eds.). Academic Press. London, UK.

McCracken, G. F., and M. K. Gustin. 1991. Nursing behaviour in Mexican free-tailed bat maternity colonies. Ethology 89:305-321.

McCracken, G. F., AND G. S. WiLKInson. 2000. Bat mating systems. Pp. 321-357 in Reproductive Biology of Bats (Crichton, E. G., and P. H. Krutzsch, eds.). Academic Press. London, UK.

McConville, A. 2013. The ecology of the east-coast free-tailed bat (Mormopterus norfolkensis) in the Hunter region. Thesis for the degree of Doctor of Philosophy. The University of Newcastle, Australia.

MenA, J., AND M. Williams. 2002. Diversidad y patrones reproductivos de quirópteros en un área urbana de Lima, Perú. Ecología Aplicada 1:1-8.

Mora, E. C., C. IBÁÑEz, S. Macías, J. Juste, I. LóPEZ, AND L. ToRres. 2011. Plasticity in echolocation inventory of Mormopterus minutus (Chiroptera: Molossidae). Acta Chiropterologica 13:179-187.

Nogueira, M. R., A. Pol, L. R. Monteiro, and A. L. Peracchi. 2008. First record of Miller's mastiff bat, Molossus pretiosus (Mammalia: Chiroptera), from the Brazilian Caatinga. Chiroptera Neotropical 14:346-353.

OLIVAL, K. J. 2012. Evolutionary and ecological correlates of population genetic structure in bats. Pp. 268-316 in Evolutionary History of Bats. Fossils, Molecules and Morphology (Gunnel, G. F., and N. B. Simmons, eds.). Cambridge University Press. New York, USA.

Ortega, J., B. Hernández-Chávez, A. Rizo-Aguilar, and J. A. GUERRERO. 2010. Estructura social y composición temporal en una colonia de Nyctinomops laticaudatus (Chiroptera: Molossidae). Revista Mexicana de Biodiversidad 81:853-862.

Ortega, J., and J. L. Martínez-Rodríguez. 2011. Conductas de apareamiento y agresión entre machos en una colonia de Nyctinomops laticaudatus (Chiroptera: Molossidae) en México. Mastozoología Neotropical 18:95-103.

Ossa, G., L. Forero, F. Novoa, ANd C. Bonacic. 2015. Caracterización morfológica y bioacústica de los murciélagos (Chiroptera) de la Reserva Nacional Pampa de Tamarugal. Biodiversidata 3:21-29.

Pacheco, V., E. Salas, L. Cairampoma, M. Noblecilla, H. Quintana., F. Ortiz, P. Palermo, and R. Ledesma. 2007. Contribución al conocimiento de la diversidad y conservación de los mamíferos de la cuenca del río Apurímac, Perú. Revista Peruana de Biología 14:169-180.

Pacheco, V., R. Cadenillas, E. Salas, C. Tello, and H. Zeballos. 2009. Diversidad y endemismo de los mamíferos del Perú. Revista Peruana de Biología 16:5-32.

Pacheco, V., A. Zevallos, K. Cervantes, J. Pacheco, and J. Salvador. 2015. Mamíferos del Refugio de Vida Silvestre Los Pantanos de Villa, Lima-Perú. Científica 12:26-41.

Papadatou, E., R. K. Butlin, and J. D. Altringham. 2008. Identification of bat species in Greece from their echolocation calls. Acta Chiropterologica 10:127-143.

Pari, A., K. Pino, C.E. Medina, E. López, and H. Zeballos. 2015. Murciélagos de Arequipa, Historia Natural y Conservación. Impresiones Juve E.I.R.L. Arequipa, Perú.

PAZ, O. DE, AND J. Benzal. 1990. Clave para la identificación de los murciélagos de la Península Ibérica (Mammalia, Chiroptera). Miscelánea Zoológica 13:153-176.

Pérez-Irineo, G., and A. Santos-Moreno. 2014. Density, distribution, and activity of the ocelot Leopardus pardalis (Carnivora: Felidae) in Southeast Mexican rainforests. Revista de Biología Tropical 62:1421-1432.

Pérez-Lustre, M., and A. Santos-Moreno. 2010. Movements and capture-recapture data analysis of the Vesper Rat (Nyctomys sumichrasti: Rodentia, Muridae) in a tropical forest in northeastern Oaxaca, México. Acta Zoológica Mexicana 26:627-638.

RACEY, P. A. 1982. Ecology of bat reproduction. Pp. 57-104 in Ecology of bats (Kunz, T. H. Ed.). Plenum Press. New York, USA. 
RACEY, P. A. 2009. Reproductive assessment of bats. Pp. 249264 in Ecological and behavioral methods for the study of bats (Kunz, T. H., and S. Parsons, eds.). The Johns Hopkins University Press. Maryland, USA.

RatCliffe, F. 1932. Notes on the fruit bats (Pteropus spp.) of Australia. Journal of Animal Ecology 1:32-37.

Rebekić, A., Z. Lončarić, S. Petrović, and S. Marić. 2015. Pearson's or Spearman's correlation coefficient - which one to use? Poljoprivreda 21:47-54

Rodríguez-San Pedro, A., D. A. Peñaranda, J. L. Allendes, and M. L. C. Castillo. 2015. Update on the distribution of Myotis atacamensis (Chiroptera: Vespertilionidae): southernmost record and description of its echolocation calls. Chiroptera Neotropical 21:1342-1346.

Rodríguez-San Pedro, A. J. L. Allendes, and G. Ossa. 2016. Lista actualizada de los murciélagos de Chile con comentarios sobre taxonomía, ecología y distribución. Biodiversity and Natural History 2:18-41.

Russo, D., AND G. Jones. 2002. Identification of twenty-two bat species (Mammalia: Chiroptera) from Italy by analysis of time-expanded recordings of echolocation calls. Journal of Zoology 258:91-103.

Santos-Moreno, A., M. Briones-Salas, and R. López-Wilchis. 2007. Diferencias en algunos parámetros demográficos de Oryzomys chapmani (Rodentia: Muridae) asociada a tres estados sucesionales de bosque mesófilo de montaña en Oaxaca, México. Acta Zoológica Mexicana 23:123-137.

Santos-Moreno, A., J. L. García-García, and A. Rodríguez-Alamilla. 2010. Ecología y reproducción del murciélago Centurio senex (Chiroptera: Phyllostomidae) en Oaxaca, México. Revista Mexicana de Biodiversidad 81:847-952.

SENAMHI. 2017. Servicio Nacional de Meteorología e Hidrología del Perú. Base de datos meteorológicos, datos históricos, Perú. http://www.senamhi.gob.pe/. Consulted on December $1^{\text {st }} 2017$.

Simmons, J. A., And R. A. Stein. 1980. Acoustic imaging in bat sonar: echolocation signals and the evolution of echolocation. Journal of Comparative Physiology 135:61-84.

Solari, S., R. BARQueZ, ANd M. Díaz. 2008. Mormopterus kalinowskii. In: IUCN 2017. The IUCN Red List of Threatened Species. Version 2017.3. www.iucnredlist.org. Consulted on February $27^{\text {th }} 2018$.

StartPoint Technologies Inc. 2010. Statgraphics Centurion XVI v16.1.11 Program distributed by the author. StartPoint Technologies Inc. Herndon, USA.

TAYLOR, R. 1990. Interpretation of the correlation coefficient: A basic review. Journal of Diagnostic Medical Sonography 1:35-39.

Vaughan, T. A., J. M. Ryan, And N. J. CZaplewskl. 2015. Mammalogy. Sixth edition. Jones and Bartlett Publishers. Massachusetts, USA. Warner, J. W., J. L. Patton, A. L. Gardner, and R. J. Baker. 1974. Karyotypic analyses of twenty-one species of molossid bats (Molossidae: Chiroptera). Canadian Journal of Genetics and Cytology 16:165-176.

WILSON, D.E. 1979. Reproductive patterns. Special Publications, the Museum, Texas Tech University 16:317-378.

ZilıaK, S. T., AND D. N. McCloskey. 2008. The cult of statistical significance: how the standard error costs us jobs, justice and lives. The University of Michigan Press. Michigan, USA.
ZORTÉA, M. 2003. Reproductive patterns and feeding Habits of three nectarivorous bats (Phyllostomidae: Glossophaginae) from the Brazilian Cerrado. Brazilian Journal of Biology 63:159-168.

Associated editor: Sergio Solari

Submitted: January 2, 2019; Reviewed: February 2, 2019;

Accepted: March 5, 2019; Published on line:July 26, 2019. 